\title{
Satisfaction Derived by the Customers on the Services Offered by the Foreign Sector Banks in Coimbatore District
}

\author{
Dr. S. Thinakaran and Dr.R. Vijayakumar
}

\begin{abstract}
Customer satisfaction on various services is considered as an important parameter for the management of banks to prepare future strategy. Today, customers are more value oriented in their consumption of services because they have alternative choices. After the emergence of foreign banks in India, the banking sector in India has become more competitive and accurate. Foreign banks have brought latest technology and latest banking practices to India. Foreign Banks in India have brought prompt services to customers. Their contribution is significant in terms of making the Indian Banking system more competitive and efficient. Hence, the present study is a fact finding exercise to measure the level of satisfaction derived by the customers of foreign sector banks in Coimbatore district and to identify the factors that influence the same.
\end{abstract}

Keywords--- Customer Satisfaction, Customer Services, Indian Banking System, Foreign Sector Banks

\section{INTRODUCTION}

$\mathrm{T}$ HE Banking Sector has been considered as an important segment of the territory sector and it contributes significantly for the economic progress of a country. The banks offer crucial services to the masses belonging to agriculture, industry and all other sectors. The role played by the banks is highly important in achieving the social and economic objectives of the country. Within the banking institutions, the role of commercial banks has acquired a new meaning and significance, in view of the changing structure and requirements of a developing economy. The commercial banks provide a range of services to the whole community in many ways. Apart from rendering the basic banking services and various other traditional and conventional services to the customers, the modern commercial banks have diversified their activities with their entry into new non-traditional areas of business. These new areas include mutual fund, merchantbanking activities, portfolio management, corporate counselling, project counselling, and hire purchase finance, equipment leasing, venture capital and factoring service [1]. The entry of foreign players in the Indian Banking Industry

Dr.S. Thinakaran, Associate Professor, GRD School of Commerce and International Business, Dr.G.R.D. College of Science (Autonomous), Coimbatore, Tamilnadu, India.E-mail: st_cbe@ rediffmail.com

Dr.R. Vijayakumar, Assistant Professor, Department of Commerce, Government Arts College (Autonomous), Coimbatore, Tamilnadu. India. Email: vijayakumarijm@gmail.com

DOI: 10.9756/BIJIEMS.1505 has brought tremendous changes in this industry. The dynamic services offered by these banks, the variety of the products offered by these banks, exploitation of the technology to the greater possible extent by these banks, offering the sophisticated services to meet out the varied demands of the variety of customers have resulted in securing a specific place for these banks in the Indian banking scenario.

\section{Statement OF THE PROBLem}

Customer satisfaction on various services is considered as an important parameter for the management of banks to prepare future strategy. Today, customers are more value oriented in their consumption of services because they have alternative choices. After the emergence of foreign banks in India, the banking sector in India has become more competitive and accurate. Foreign banks have brought latest technology and latest banking practices to India. Foreign Banks in India have brought prompt services to customers. Their contribution is significant in terms of making the Indian Banking system more competitive and efficient. The Coimbatore District is the second largest industrial city in the State of Tamilnadu and it is also popularly known as 'The Manchester of South India' and 'Textile Capital of South India' as it has the presence of a large number of textile units. The presence of more number of industries offers a wider scope for the banking activities in this district. As a result, there exists a cut throat competition among the banks which fall under different categories to retain the existing customers and to acquire new customers. In order to remain more competitive and to ensure their survival in the competitive banking environment, the banks of various sectors formulate and implement various customer centric policies. These policies are formulated and implemented by the banks with a view to offer a superior level of satisfaction to the customers on the services offered by them. . The foreign sector banks are very sound in terms of technological innovations and implementations of sophisticated technologies. As a result, these banks are able to offer diversified products to suit to the multifaceted requirements of different kinds of customers. Hence, the present study is a fact finding exercise to measure the level of satisfaction derived by the customers of foreign sector banks in Coimbatore district and to identify the factors that influence the same.

\section{FOREIGN SECTOR BANKS IN INDIA}

The Government of India set up a High Level Committee with Mr. M. Narasimham, a former Governor of Reserve Bank of India as the Chairman, to examine all aspects relating to the 
structure, organization, functions and procedures of the financial system in July, 1991, and this Committee on the Financial System submitted its report in November, 1991. In accordance with the recommendations of the Committee, the Government has permitted individuals, corporations, foreign and non-resident individuals to open private banks in India [2]. There has been a steady increase in the number of foreign banks and their branches operating in India. At the end of September 2010, 34 foreign banks (from 24 countries) were operating in India as compared to 32 banks at the end of June, 2009. The total number of branches too increased to 315 in 2010 from 293 in 2009. In addition, 45 foreign banks operated in India through representative offices in 2010 as against 43 in 2009 [3].

\section{LITERATURE REVIEW}

1. Biff Motley [4] in his study "Customer Satisfaction Vs Customer Service" emphasized that the outcome of such expenses should be customer satisfaction for which customer services is a mean or a strategy. Sometimes customer services are very well thought out, based upon a detailed understanding of what customers expect and supported with great resources and management attention. These are usually successful because they are very well focused.

2. Bryant Duhon [5] in his study "Customer Service for Life", has highlighted the importance and advantages of electronic document management system to improve customer service. The need for a strategic policy that would immediately enable better customer service and pave the way for e-commerce initiatives has been emphasized.

3. M. Selvam [6], in his article titled "Customer Satisfaction of Banking Services : An Over View" concluded that banks, both public sector as well as private sector, have to gear up their speed to adapt to the fast changing technology.. Banks have to evolve plans and strategies to provide better services and enhance satisfaction level and try to create a brand image. As this arena is proving to be very competitive for the existing as well as emerging banks, every bank should keenly focus every aspect of the services provided to the customer, if they want to survive in this competitive world.

4. The results of the study conducted by R. Vijayakumar, [7] titled "Customer Satisfaction in Private Sector Banks in Coimbatore" revealed that the factors viz., Account Opening Formalities, Working Hours of the Banks, Interest Rate on Deposits, Products Offered by the Banks, Loan Sanctioning Procedure, Quantum of Loans Sanctioned by the Banks, Efficiency of Staff, Value Added Services Offered by the Banks, Time Taken to Serve the Customers, Ambience Facilities in the Banks, Customer Dispute Settling Mechanism, Relationship Maintained by the Bank with Their Customers and Overall Quality of Services of the Banker significantly influence the satisfaction derived by the customers of Private Sector Banks in Coimbatore.

5. The study "Digital Banking" conducted by Dr. R Vijayakumar [8] revealed that the entry of new banks in
Indian banking industry has resulted in a paradigm shift in the ways of banking in India. The arrival of foreign and private banks with their superior state-of-the-art technology-based services pushed Indian banks also to follow suit by going in for the latest technologies so as to meet the threat of competition and retain their customer base.

6. In their study titled as "Customers' perception on the services of New Generation Private Sector Banks in Coimbatore District" conducted by R.Vijayakumar., and B. Kanagaraj,[9] suggested that implementation of the factors such as establishing a comprehensive customer information system, adopting well formulated strategies for maintaining long term relationship with the customers, organizing customers contact programmes on a regular basis, strengthening the internet banking base, establishing customer grievance redressal cell, more focus on offering number of value added services, customer education, designing and implementing effective customer relationship management, designing and adopting effective customer oriented strategies and practices, total commitment of the staff in bank creation of a conducive banking atmosphere and provision of adequate amenities will result in provision of a superior quality of the services by the New Generation Banks to their customers.

7. Pooja Mengi [10] in her study on "Customer Satisfaction with Service Quality: An Empirical Study of Public and Private Sector Banks" mentioned that Customer service is an integral part of any facet of banking and it defines the future of any banking organization. This study compares customers' perceptions of service quality of public and private banks of Jammu. The service quality of both the banks has been measured using SERVQUAL (service quality) scale. It was found that customers of public sector banks are more satisfied with the service quality than those of private sector banks.

8. An article on "Service Quality, Customer Satisfaction, and Customer Loyalty in Indian Commercial Banks" by Usha Lenka, Damodar Suar, Pratap K J Mohapatra [11] examines whether service quality of Indian commercial banks increases customer satisfaction that fosters customer loyalty. Results suggest that better human, technical and tangible aspects of service quality of the bank branches increase customer satisfaction. Customer satisfaction furthers customer loyalty. Increase in service quality of the banks can satisfy and retain customers. In the Indian banking sector, human aspects are more important than technical and tangible aspects of service quality that influence customer satisfaction and promote and enhance customer loyalty.

9. In a study titled "A causal relationship between Information Technology and customer satisfaction - a case study on Indian public sector banks" Saroj Kumar [12] revealed that Customer satisfaction being a prerequisite for organizational survival and growth, Indian PSBs are also getting equipped with more and more new products and services which demand more technological solutions. This paper focuses on the impact of information technology on Indian PSBs and how this is 
affecting the level of their customer satisfaction.

\section{OBJECTIVES}

The present study has been undertaken with the following specific objectives:

a. To measure the level of satisfaction derived by the customers on the services offered by the Foreign Sector Banks in Coimbatore District

b. To assess the factors that influence the satisfaction derived by the customers of Foreign Sector Banks in Coimbatore District

c. To offer suggestions for enhancing the satisfaction of the customers on the services offered by the Foreign Sector Banks.

\section{METHOdOLOGY AND TOOLS USED}

The study is based on primary data and the required data for the study were collected through structured questionnaire from two hundred customers of various Foreign Sector Banks in Coimbatore. The respondents for the study were drawn by means of employing simple random sampling method. In order to find out the relationship between the various particulars relating to the sample respondents and the satisfaction derived by them on the services offered by the Foreign Sector Banks, chi - square test was employed.

\section{EXTENT OF VARIATION IN THE SATISFACTION DERIVED BY THE SAMPLE RESPONDENTS}

The respondents of the study were divided in to three groups in accordance with their respective satisfaction scores such as 'less satisfied respondents' (the respondents with the satisfaction scores upto 43.84), 'medium satisfied respondents' (the respondents with the scores between 43.85 and 85.66) and 'highly satisfied respondents' (the respondents with the scores above 85.66). The extent of variation in the level of satisfaction derived by the respondents is given in Table -1 .

Table 1: Extent of Variation in Customer Satisfaction

\begin{tabular}{|c|c|c|}
\hline Level of satisfaction & Number of respondents & Percentage \\
\hline Low & 38 & 19.00 \\
\hline Medium & 68 & 34.00 \\
\hline High & 94 & 47.00 \\
\hline Total & 200 & 100.00 \\
\hline
\end{tabular}

Source: Survey Data

Table -1 indicates that thirty eight respondents (19.00\%) derived lower level of satisfaction, sixty eight respondents $(34.00 \%)$ derived medium level of satisfaction and the remaining ninety four respondents $(47.00 \%)$ derived higher level of satisfaction on the services of Foreign Sector Banks in Coimbatore.

\section{LEVEL OF CUSTOMER SATISFACTION}

The level of satisfaction derived by the respondents on the various services rendered by the Foreign Sector banks in Coimbatore is presented in the following paragraphs:

\section{A. Respondents' Opinion on Account Opening Formalities and Level of Satisfaction}

The distribution of the respondents on the basis of their opinion on the Account Opening Formalities and the level of customer satisfaction is presented in Table - 2. It indicates that the account opening formalities are complicated for thirty one respondents $(15.60 \%)$, simple for thirty seven respondents $(18.50 \%)$ and the same is very simple for the remaining one hundred and thirty two (66.00\%) respondents.

Table 2: Respondents Opinion On Account Opening Formalities

\begin{tabular}{|c|c|c|c|c|}
\hline \multirow{2}{*}{$\begin{array}{c}\text { Account } \\
\text { Opening } \\
\text { Formalities }\end{array}$} & \multicolumn{3}{|c|}{ Level of Satisfaction } & \multirow[b]{2}{*}{ Total } \\
\hline & Low & Medium & High & \\
\hline Complicated & $\begin{array}{c}10 \\
(32.26 \%)\end{array}$ & $\begin{array}{c}10 \\
(32.26 \%)\end{array}$ & $11(35.48 \%)$ & 31 \\
\hline Simple & $\begin{array}{c}16 \\
(43.24 \%)\end{array}$ & $\begin{array}{c}9 \\
(24.32 \%)\end{array}$ & $12(32.43 \%)$ & 37 \\
\hline Very simple & $\begin{array}{c}12 \\
(9.09 \%)\end{array}$ & $\begin{array}{c}49 \\
(37.12 \%)\end{array}$ & $71(53.79 \%)$ & 132 \\
\hline Total & 38 & 68 & 94 & 200 \\
\hline \multicolumn{5}{|c|}{$\chi^{2}$ value $=47.09$} \\
\hline
\end{tabular}

Source: Survey Data

(Figures given in the brackets represent the Percentage to the total)

Null Hypothesis: The association between the opinion of the respondents on the account opening formalities and their level of satisfaction is not significant.

Table -2 reveals that the majority of the respondents $(66.00 \%)$ opined that the account opening formalities are very simple. It further indicates that the percentage of respondents with low level of satisfaction is the lowest (9.09\%) and the percentage of respondents with high level of satisfaction is the highest (53.79\%) among the respondents who opined that the account opening formalities are very simple. As the calculated $\chi^{2}$ value (47.09) is greater than the table value (9.488) at $5 \%$ level of significance for 4 degrees of freedom, the null hypothesis is rejected and it could be concluded that the association between the opinion of the respondents on the account opening formalities and their level of satisfaction is significant.

\section{B. Respondents' opinion on Working Hours of the Banks and Level of Satisfaction}

The distribution of the respondents on the basis of their opinion on the working hours of the banks and the level of customer satisfaction is presented in Table - 3 . It indicates that the working hours of the banks are not convenient for thirty three respondents $(16.50 \%)$, convenient for forty six respondents $(23.00 \%)$ and the same is more convenient for the remaining one hundred and twenty one respondents $(60.50 \%)$.

Null Hypothesis: The association between the opinion of the respondents on the working hours of the banks and their level of satisfaction is not significant. 
Table 3: Opinion of Working Hours

\begin{tabular}{|c|c|c|c|c|}
\hline \multirow{2}{*}{ Working Hours } & \multicolumn{3}{|c|}{ Level of Satisfaction } & \multirow{2}{*}{ Total } \\
\hline & Low & Medium & High & \\
\hline Not convenient & $\begin{array}{c}11 \\
(33.33 \%) \\
\end{array}$ & $\begin{array}{c}11 \\
(33.33 \%) \\
\end{array}$ & $\begin{array}{c}11 \\
(33.33 \%) \\
\end{array}$ & 33 \\
\hline Convenient & $\begin{array}{c}13 \\
(28.26 \%) \\
\end{array}$ & $\begin{array}{c}19 \\
(41.30 \%)\end{array}$ & $\begin{array}{c}14 \\
(30.43 \%) \\
\end{array}$ & 46 \\
\hline $\begin{array}{c}\text { More } \\
\text { Convenient }\end{array}$ & $\begin{array}{c}14 \\
(11.57 \%)\end{array}$ & $\begin{array}{c}38 \\
(31.40 \%)\end{array}$ & $\begin{array}{c}69 \\
(57.02 \%)\end{array}$ & 121 \\
\hline Total & 38 & 68 & 94 & 200 \\
\hline & $\chi^{2}$ & 38.22 & & \\
\hline
\end{tabular}

Source: Survey Data

Table - 3 reveals that majority of the respondents $(60.50 \%)$ opined that the working hours of the bank are more convenient to them. It further indicates that the percentage of respondents with low level of satisfaction is the lowest (11.57 $\%)$ and the percentage of respondents with high level of satisfaction is the highest (57.02\%) among the respondents who opined that the working hours of the banks are more convenient.As the calculated $\chi^{2}$ value (38.22) is greater than the table value (9.488) at 5\% level of significance for 4 degrees of freedom, the null hypothesis is rejected and it could be concluded that the association between the opinion of the respondents on the working hours of the banks and their level of satisfaction is significant.

\section{Respondents' Opinion on Interest Rate on Deposits and Level of Satisfaction}

The distribution of the respondents on the basis of their opinion on the interest rates offered on the deposits and the level of customer satisfaction is presented in Table - 4. It indicates that the interest rates offered by the banks are low for thirty nine respondents $(19.50 \%)$, moderate for forty two respondents $(21.00 \%)$ and high for one hundred and nineteen respondents $(59.50 \%)$.

Table 4: Opinion on Interest Rate on Deposits

\begin{tabular}{|c|c|c|c|c|}
\hline \multirow{2}{*}{$\begin{array}{c}\text { Interest Rate on } \\
\text { Deposits }\end{array}$} & \multicolumn{3}{|c|}{ Level of Satisfaction } & \multirow{2}{*}{ Total } \\
\hline & Low & Medium & High & \\
\hline Low & $\begin{array}{c}9 \\
(23.08 \%)\end{array}$ & $\begin{array}{c}13 \\
(33.33 \%)\end{array}$ & $\begin{array}{c}17 \\
(43.59 \%)\end{array}$ & 39 \\
\hline Moderate & $\begin{array}{c}11 \\
(26.19 \%)\end{array}$ & $\begin{array}{c}13 \\
(30.95 \%)\end{array}$ & $\begin{array}{c}18 \\
(42.86 \%)\end{array}$ & 42 \\
\hline High & $\begin{array}{c}18 \\
(15.13 \%)\end{array}$ & $\begin{array}{c}42 \\
(35.29 \%)\end{array}$ & $\begin{array}{c}59 \\
(49.58 \%)\end{array}$ & 119 \\
\hline Total & 38 & 68 & 94 & 200 \\
\hline \multicolumn{5}{|c|}{$\chi^{2}$ value $=32.32$} \\
\hline
\end{tabular}

Source: Survey Data

Null Hypothesis: The association between the opinion of the respondents on the Interest Rate on Deposits offered by the banks and their level of satisfaction is not significant.

Table -4 reveals that majority of the respondents (59.50\%) opined that the interest rates offered by the banks on the deposits is high. It further indicates that the percentage of respondents with low level of satisfaction is the lowest $(15.13 \%)$ and the percentage of respondents with high level of satisfaction is the highest $49.58 \%$ ) among the respondents who opined that the banks offer higher rate of interest on deposits of the customers. As the calculated $\chi^{2}$ value (32.32) is greater than the table value (9.488) at 5\% level of significance for 4 degrees of freedom, the null hypothesis is rejected and it could be concluded that the association between the opinion of the respondents on the Interest Rate on Deposits offered by the banks and their level of satisfaction is significant.

\section{Respondents' Opinion on Products Offered by the Banks and Level of Satisfaction}

The distribution of the respondents on the basis of their opinion on the products offered by the banks and the level of customer satisfaction is presented in Table -5 . It indicates that the products offered by the banks are less for twenty seven respondents (13.50\%), more for forty four respondents $(22.00 \%)$ and plenty for the remaining one hundred and twenty nine $(64.50 \%)$ respondents.

Table 5: Opinion on Products Offered by the Banks

\begin{tabular}{|c|c|c|c|c|}
\hline \multirow{2}{*}{$\begin{array}{c}\text { Products Offered } \\
\text { by the Banks }\end{array}$} & \multicolumn{3}{|c|}{ Level of Satisfaction } & \multirow{2}{*}{ Total } \\
\hline & Low & Medium & High & \\
\hline Few & $\begin{array}{c}9 \\
(33.33 \%)\end{array}$ & $\begin{array}{c}11 \\
(40.74 \%)\end{array}$ & $\begin{array}{c}7 \\
(25.93 \%)\end{array}$ & 27 \\
\hline Moderate & $\begin{array}{c}12 \\
(27.27 \%) \\
\end{array}$ & $\begin{array}{c}19 \\
(43.18 \%) \\
\end{array}$ & $\begin{array}{c}13 \\
(29.55 \%) \\
\end{array}$ & 44 \\
\hline Many & $\begin{array}{c}17 \\
(13.18 \%)\end{array}$ & $\begin{array}{c}38 \\
(29.46 \%)\end{array}$ & $\begin{array}{c}74 \\
(57.36 \%)\end{array}$ & 129 \\
\hline Total & 38 & 68 & 94 & 200 \\
\hline
\end{tabular}

Source: Survey Data

Null Hypothesis: The association between the opinion of the respondents on the Products Offered by the Banks and their level of satisfaction is not significant.

Table -5 reveals that majority of the respondents $(64.50 \%)$ opined that the banks offer many products to them. It further indicates that the percentage of respondents with low level of satisfaction is the lowest (13.18\%) and the percentage of respondents with high level of satisfaction is the highest $(57.36 \%)$ among the respondents who opined that the banks offer many products. As the calculated $\chi^{2}$ value (64.58) is greater than the table value (9.488) at 5\% level of significance for 4 degrees of freedom, the null hypothesis is rejected and it could be concluded that the association between the opinion of the respondents on the Products Offered by the Banks and their level of satisfaction is significant.

\section{E. Respondents' Opinion on Loan Sanctioning Procedure and Level of Satisfaction}

The distribution of the respondents on the basis of their opinion on the loan sanctioning procedure and the level of customer satisfaction is presented in Table -6 . It indicates that the loan sanctioning procedures in the banks are complicated for thirty five respondents $(17.50 \%)$, simple for sixty one respondents $(30.50 \%)$ and very simple for the remaining one hundred and four respondents (52.00\%).

Null Hypothesis: The association between the opinion of the respondents on the Loan Sanctioning Procedures of the Banks and their level of satisfaction is not significant. 
Table 6: Opinion on Loan Sanctioning Procedure

\begin{tabular}{|c|c|c|c|c|}
\hline \multirow{2}{*}{$\begin{array}{c}\text { Loan Sanctioning } \\
\text { Procedure }\end{array}$} & \multicolumn{3}{|c|}{ Level of Satisfaction } & \multirow{2}{*}{ Total } \\
\cline { 2 - 4 } Complicated & $\begin{array}{c}16 \\
(45.71 \%)\end{array}$ & $\begin{array}{c}12 \\
(34.29 \%)\end{array}$ & $\begin{array}{c}7 \\
(20.00 \%)\end{array}$ & 35 \\
\hline Easy & 11 & 24 & 26 & \\
& $(18.03 \%)$ & $(39.34 \%)$ & $(42.62 \%)$ & 61 \\
\hline Very Easy & 11 & $\begin{array}{c}32 \\
(10.58 \%)\end{array}$ & $\begin{array}{c}61 \\
(30.77 \%)\end{array}$ & \multirow{2}{*}{$\begin{array}{c}68.65 \%) \\
104\end{array}$} \\
\hline Total & 38 & 68 & 94 & 200 \\
\hline \multicolumn{4}{|c|}{$\chi^{2}$ value = 40.03 } \\
\hline
\end{tabular}

Source: Survey Data

Table -6 reveals that majority of the respondents $(52.00 \%)$ opined that the loan sanctioning procedures are easy. It further indicates that the percentage of respondents with low level of satisfaction is the lowest (10.58\%) and the percentage of respondents with high level of satisfaction is the highest (58.65\%) among the respondents who opined that loan sanctioning procedure in the banks are very easy. As the calculated $\chi^{2}$ value (40.03) is greater than the table value (9.488) at $5 \%$ level of significance for 4 degrees of freedom, the null hypothesis is rejected and it could be concluded that the association between the opinion of the respondents on the Loan Sanctioning Procedures of the Banks and their level of satisfaction is significant.

\section{F. Respondents' Opinion On Quantum of loans sanctioned by} the banks and Level of Satisfaction:

The distribution of the respondents on the basis of their opinion on quantum of loans sanctioned by the bank and the level of customer satisfaction is presented in Table - 7. It indicates that the quantum of loans offered by the banks is inadequate for forty four respondents $(22.00 \%)$, fairly adequate for fifty four respondents $(27.00 \%)$ and adequate for the remaining one hundred and two $(51.00 \%)$ respondents

Table 7: Opinion on Quantum of Loans Sanctioned by the Banks

\begin{tabular}{|c|c|c|c|c|}
\hline \multirow{2}{*}{$\begin{array}{c}\text { Quantum of } \\
\text { Loans Sanctioned } \\
\text { by the Banks }\end{array}$} & \multicolumn{3}{|c|}{ Level of Satisfaction } & \multirow{2}{*}{ Tota } \\
\hline & Low & Medium & High & \\
\hline Inadequate & $\begin{array}{c}12 \\
(27.27 \%)\end{array}$ & $\begin{array}{c}19 \\
(43.18 \%)\end{array}$ & $\begin{array}{c}13 \\
(29.55 \%)\end{array}$ & 44 \\
\hline Fairly Adequate & $\begin{array}{c}16 \\
(29.63 \%)\end{array}$ & $\begin{array}{c}20 \\
(37.04 \%)\end{array}$ & $\begin{array}{c}18 \\
(33.33 \%)\end{array}$ & 54 \\
\hline Adequate & $\begin{array}{c}10 \\
(9.80 \%)\end{array}$ & $\begin{array}{c}29 \\
(28.43 \%)\end{array}$ & $\begin{array}{c}63 \\
(61.76 \%)\end{array}$ & 102 \\
\hline Total & 38 & 68 & 94 & 200 \\
\hline \multicolumn{5}{|c|}{$\chi^{2}$ value $=53.09$} \\
\hline
\end{tabular}

Source: Survey Data

Null Hypothesis: The association between the opinion of the respondents on the Quantum of Loans Sanctioned by the Banks and their level of satisfaction is not significant.

Table -7 reveals that majority of the respondents (51.00\%) opined that the banks offer adequate amount of loans to them. It further indicates that the percentage of respondents with low level of satisfaction is the lowest $(9.80 \%)$ and the percentage of respondents with high level of satisfaction is the highest (61.76\%) among the respondents who opined that the quantum of loans sanctioned by the banks is adequate. As the calculated $\chi^{2}$ value (53.09) is greater than the table value $(9.488)$ at $5 \%$ level of significance for 4 degrees of freedom, the null hypothesis is rejected and it could be concluded that the association between the opinion of the respondents on the Quantum of Loans Sanctioned by the Banks and their level of satisfaction is significant.

\section{G. Respondents' opinion on Efficiency of Staff and Level of Satisfaction:}

The distribution of the respondents on the basis of their opinion on efficiency of staff and the level of customer satisfaction is presented in Table -8 . It indicates that the staff are less efficient for forty tow respondents $(21.00 \%)$, efficient for sixty two respondents $(31.00 \%)$ and very efficient for ninety six respondents $(46.50 \%)$.

Table 8: Opinion on Efficiency of Staff

\begin{tabular}{|c|c|c|c|c|}
\hline \multirow{2}{*}{$\begin{array}{c}\text { Efficiency of } \\
\text { Staff }\end{array}$} & \multicolumn{3}{|c|}{ Level of Satisfaction } & \multirow{2}{*}{ Total } \\
\cline { 2 - 4 } Less Efficient & $\begin{array}{c}14 \\
(33.33 \%)\end{array}$ & $\begin{array}{c}17 \\
(40.48 \%)\end{array}$ & $\begin{array}{c}11 \\
(26.19 \%)\end{array}$ & \multirow{2}{*}{42} \\
\hline \multirow{2}{*}{ Efficient } & 13 & 37 & 12 & \\
& $(20.97 \%)$ & $(59.68 \%)$ & $(19.35 \%)$ & 62 \\
\hline Very efficient & 11 & $\begin{array}{c}14 \\
(11.46 \%)\end{array}$ & $\begin{array}{c}71 \\
(73.58 \%)\end{array}$ & 96 \\
\hline Total & 38 & 68 & 94 & 200 \\
\hline \multicolumn{4}{|c|}{$\chi^{2}$ value $=86.9018$} \\
\hline
\end{tabular}

Source: Survey Data

Null Hypothesis: The association between the opinion of the respondents on the Efficiency of the Staff in the Banks and their level of satisfaction is not significant.

Table -8 reveals that majority $(46.50 \%)$ of the respondents opined that the staff in the Banks are very efficient. It further indicates that the percentage of respondents with low level of satisfaction is the lowest $(11.46 \%)$ and the percentage of respondents with high level of satisfaction is the highest (73.96\%) among the respondents who opined that the staffs are very efficient. As the calculated $\chi^{2}$ value (86.90) is greater than the table value $(9.488)$ at $5 \%$ level of significance for 4 degrees of freedom, the null hypothesis is rejected and it could be concluded that the association between the opinion of the respondents on the Efficiency of the Staff in the Banks and their level of satisfaction is significant.

\section{H. Respondents' opinion on Value Added Services offered by the banks and Level of Satisfaction}

The distribution of the respondents on the basis of their opinion on the value added services offered by the banks and the level of customer satisfaction is presented in Table -9. It indicates that the value added services offered by the banks are less for forty one respondents (20.50\%), adequate for fifty four respondents $(27.00 \%)$ and plenty for one hundred and five respondents $(52.50 \%)$. 
Table 9: Opinion on Value Added Services Offered by the Banks

\begin{tabular}{|c|c|c|c|c|}
\hline Value Added & \multicolumn{3}{|c|}{ Level of Satisfaction } & \multirow{2}{*}{ Total } \\
\cline { 2 - 4 } Services & Low & Medium & High & \\
\hline \multirow{2}{*}{ Less } & $\begin{array}{c}11 \\
(26.83 \%)\end{array}$ & $\begin{array}{c}17 \\
(41.46 \%)\end{array}$ & $\begin{array}{c}13 \\
(31.71 \%)\end{array}$ & 41 \\
\hline \multirow{2}{*}{ Adequate } & 15 & 18 & 21 & \\
& $(27.78 \%)$ & $(33.33 \%)$ & $(38.89 \%)$ & 54 \\
\hline Plenty & 12 & $\begin{array}{c}33 \\
(11.43 \%)\end{array}$ & $\begin{array}{c}60 \\
(31.43 \%)\end{array}$ & \multirow{2}{*}{$67.14 \%)$} \\
\hline Total & 38 & 68 & 94 & 200 \\
\hline \multicolumn{4}{|c|}{$\chi^{2}$ value $=42.49$} \\
\hline
\end{tabular}

Source: Survey Data

Null Hypothesis: The association between the opinion of the respondents on the Value Added Services Offered by the Banks and their level of satisfaction is not significant.

Table - 9 reveals that majority of the respondents $(52.50 \%)$ opined that the banks offer more value added services to them. It further indicates that the percentage of respondents with low level of satisfaction is the lowest $(11.43 \%)$ and the percentage of respondents with high level of satisfaction is the highest (57.14\%) among the respondents who opined that the banks offer more value added services. As the calculated $\chi^{2}$ value $(42.49)$ is greater than the table value (9.488) at 5\% level of significance for 4 degrees of freedom, the null hypothesis is rejected and it could be concluded that the association between the opinion of the respondents on the Value Added Services Offered by the Banks and their level of satisfaction is significant.

\section{Respondents' Opinion on Time Taken for Serving the Customers and Level of Satisfaction:}

The opinion of the respondents on the time taken by the banks for serving the customers is presented in Table - 10. It indicates that thirty nine respondents (19.50\%)opined that the banks take more time for serving the customers, forty respondents $(20.00 \%)$ opined that the time taken for serving the customers is normal and the remaining one hundred and twenty one respondents $(60.50 \%$ opined that the banks take less time for serving the customers.

Table 10: Time Taken for Serving the Customers

\begin{tabular}{|c|c|c|c|c|}
\hline \multirow{2}{*}{$\begin{array}{c}\text { Time Taken } \\
\text { for Serving }\end{array}$} & \multicolumn{3}{|c|}{ Level of Satisfaction } & \multirow{2}{*}{ Total } \\
\cline { 2 - 4 } More & 12 & Medium & High & \\
\hline \multirow{2}{*}{ Normal } & $(30.77 \%)$ & $\begin{array}{c}12 \\
(30.77 \%)\end{array}$ & $\begin{array}{c}15 \\
(38.46 \%)\end{array}$ & 39 \\
\hline \multirow{2}{*}{ Less } & $\begin{array}{c}12 \\
(30.00 \%)\end{array}$ & $\begin{array}{c}10 \\
(25.00 \%)\end{array}$ & $\begin{array}{c}18 \\
(45.00 \%)\end{array}$ & 40 \\
\hline Total & $(11.57 \%)$ & $\begin{array}{c}46 \\
(38.02 \%)\end{array}$ & $\begin{array}{c}61 \\
(50.41 \%)\end{array}$ & 121 \\
\hline \multicolumn{5}{|c|}{$\chi^{2}$ value $=42.49$} \\
\hline
\end{tabular}

Source: Survey Data

Null Hypothesis: The association between the opinion of the respondents on the Speed of Operation and their level of satisfaction is not significant.

Table - 10 reveals that majority of the respondents $(60.50 \%)$ opined that the bank takes less time for serving the customers. It further indicates that the percentage of respondents with low level of satisfaction is the lowest $(11.57 \%)$ and the percentage of respondents with high level of satisfaction is the highest $(50.41 \%)$ among the respondents who opined that the banks take less time for serving the customers. As the calculated $\chi^{2}$ value (42.49) is greater than the table value (9.488) at 5\% level of significance for 4 degrees of freedom, the null hypothesis is rejected and it could be concluded that the association between the opinion of the respondents on the Speed of Operation and their level of satisfaction is significant.

\section{J. Respondents' opinion on Ambiance Facilities in the Banks and Level of Satisfaction:}

The distribution of the respondents on the basis of their opinion on the ambiance facilities in the banks and the level of customer satisfaction is presented in Table - 11. It indicates that the ambiance facilities in the banks are inadequate for thirty four respondents (17.00\%), adequate for fifty one respondents $(25.50 \%)$ and plenty for the remaining one hundred and fifteen respondents $(57.50 \%)$.

Table 11: Opinion on Ambiance Facilities in the Banks

\begin{tabular}{|c|c|c|c|c|}
\hline \multirow{2}{*}{$\begin{array}{c}\text { Ambiance } \\
\text { Facilities in } \\
\text { the Banks }\end{array}$} & \multicolumn{3}{|c|}{ Level of Satisfaction } & \multirow{2}{*}{ Total } \\
\cline { 2 - 4 } In adequate & $\begin{array}{c}11 \\
(32.35 \%)\end{array}$ & $\begin{array}{c}12 \\
(35.29 \%)\end{array}$ & $\begin{array}{c}11 \\
(32.35 \%)\end{array}$ & 34 \\
\hline Adequate & $\begin{array}{c}16 \\
(31.37 \%)\end{array}$ & $\begin{array}{c}16 \\
(31.37 \%)\end{array}$ & $\begin{array}{c}19 \\
(37.25 \%)\end{array}$ & 51 \\
\hline Plenty & 11 & 40 & 64 & \\
& $(9.57 \%)$ & $(34.78 \%)$ & $(55.65 \%)$ & 115 \\
\hline Total & 38 & 68 & 94 & 200 \\
\hline \multicolumn{4}{|c|}{$\chi^{2}$ value $=39.89$} \\
\hline
\end{tabular}

Source: Survey Data

Null Hypothesis: The association between the opinion of the respondents on the Ambiance Facilities available in the Banks and their level of satisfaction is not significant.

Table - 11 reveals that majority of the respondents $(57.50 \%)$ opined that the ambiance facilities in the banks are plenty. It further indicates that the percentage of respondents with low level of satisfaction is the lowest (9.57\%) and the percentage of respondents with high level of satisfaction is the highest $(55.65 \%)$ among the respondents who opined that the ambiance facilities in the banks are plenty. As the calculated $\chi^{2}$ value (39.89) is greater than the table value $(9.488)$ at $5 \%$ level of significance for 4 degrees of freedom, the null hypothesis is rejected and it could be concluded that the association between the opinion of the respondents on the Ambiance Facilities available in the Banks and their level of satisfaction is significant.

\section{K. Respondents' opinion on Customer Dispute Settlement Mechanism and Level of Satisfaction}

The distribution of the respondents on the basis of their opinion on the functioning of the customer disputes settlement mechanism and the level of customer satisfaction is presented in Table - 12. It indicates that mechanism for settling the customer disputes is less efficient for forty two respondents, $(21.00 \%)$, efficient for sixty seven respondents $(33.50 \%)$ and more efficient for ninety one respondents $(45.50 \%)$. 
Table 12: Opinion on Customer Dispute Settlement Mechanism

\begin{tabular}{|c|c|c|c|c|}
\hline \multirow{2}{*}{$\begin{array}{l}\text { Customer } \\
\text { Dispute } \\
\text { Settlement } \\
\text { Mechanism }\end{array}$} & \multicolumn{3}{|c|}{ Level of Satisfaction } & \multirow{2}{*}{ Total } \\
\hline & Low & Medium & High & \\
\hline Less Efficient & $\begin{array}{c}16 \\
(38.10 \%) \\
\end{array}$ & $\begin{array}{c}18 \\
(42.86 \%) \\
\end{array}$ & $\begin{array}{c}8 \\
(19.05 \%) \\
\end{array}$ & 42 \\
\hline Efficient & $\begin{array}{c}11 \\
(16.42 \%)\end{array}$ & $\begin{array}{c}32 \\
(47.76 \%) \\
\end{array}$ & $\begin{array}{c}24 \\
(35.82 \%) \\
\end{array}$ & 67 \\
\hline Very Efficient & $\begin{array}{c}11 \\
(12.09 \%)\end{array}$ & $\begin{array}{c}18 \\
(19.78 \%)\end{array}$ & $\begin{array}{c}62 \\
(68.13 \%) \\
\end{array}$ & 91 \\
\hline Total & 38 & 68 & 94 & 200 \\
\hline \multicolumn{5}{|c|}{$\chi^{2}$ value $=61.96$} \\
\hline
\end{tabular}

Source: Survey Data

Null Hypothesis: The association between the opinion of the respondents on the Customer Dispute Settlement Mechanism of the Banks and their level of satisfaction is not significant.

Table - 12 reveals that majority of the respondents (45.50\%) opined that the functioning of the dispute settlement mechanism in the banks is very efficient. It further indicates that the percentage of respondents with low level of satisfaction is the lowest $(12.09 \%)$ and the percentage of respondents with high level of satisfaction is the highest (68.13\%) among the respondents who opined that the mechanism for settling customer disputes is very efficient. As the calculated $\chi^{2}$ value (61.96) is greater than the table value (9.488) at $5 \%$ level of significance for 4 degrees of freedom, the null hypothesis is rejected and it could be concluded that the association between the opinion of the respondents on the Customer Dispute Settlement Mechanism of the Banks and their level of satisfaction is significant.

\section{Respondents' opinion on the customer relationship maintained by the banks and Level of Satisfaction:}

The distribution of the respondents on the basis of their opinion on the relationship maintained by the bankers with their customers and the level of customer satisfaction is presented in Table - 13. It indicates that the customer relationship maintained by the banker is poor for forty five respondents $(22.50 \%)$, fair for forty seven respondents $(23.50 \%)$ and the same is good for one hundred and eight respondents $(54.00 \%)$.

Table 13: Opinion on Customer Relationship Maintained by the Banks

\begin{tabular}{|c|c|c|c|c|}
\hline \multirow{2}{*}{$\begin{array}{c}\text { Customer } \\
\text { Relationship }\end{array}$} & \multicolumn{3}{|c|}{ Level of Satisfaction } & \multirow{2}{*}{ Total } \\
\hline & Low & Medium & High & \\
\hline Poor & $\begin{array}{c}12 \\
(26.67 \%)\end{array}$ & $\begin{array}{c}22 \\
(48.89 \%)\end{array}$ & $\begin{array}{c}11 \\
(24.44 \%)\end{array}$ & 45 \\
\hline Fair & $\begin{array}{c}14 \\
(29.79 \%)\end{array}$ & $\begin{array}{c}21 \\
(44.68 \%)\end{array}$ & $\begin{array}{c}12 \\
(25.53 \%)\end{array}$ & 47 \\
\hline Good & $\begin{array}{c}12 \\
(11.11 \%)\end{array}$ & $\begin{array}{c}25 \\
(23.15 \%)\end{array}$ & $\begin{array}{c}71 \\
(65.74 \%)\end{array}$ & 108 \\
\hline Total & 38 & 68 & 94 & 200 \\
\hline \multicolumn{5}{|c|}{$\chi^{2}$ value $=66.42$} \\
\hline
\end{tabular}

Source: Survey Data
Null Hypothesis: The association between the opinion of the respondents on the Personal Touch Maintained by the Banks and their level of satisfaction is not significant.

Table - 13 reveals that majority of the respondents (54.00\%) opined that the banks maintain good customer relations. It further indicates that the percentage of respondents with low level of satisfaction is the lowest $(11.11 \%)$ and the percentage of respondents with high level of satisfaction is the highest $(65.74 \%)$ among the respondents who opined that the level of customer relationship maintained by the banker is good. As the calculated $\chi^{2}$ value (66.42) is greater than the table value (9.488) at $5 \%$ level of significance for 4 degrees of freedom, the null hypothesis is rejected and it could be concluded that the association between the opinion of the respondents on customer relationship maintained by the Banks and their level of satisfaction is significant.

\section{Respondents' opinion on the E-Banking Facilities Offered by the Banks and Level of Satisfaction}

The distribution of the respondents on the basis of their opinion on the $\mathrm{E}$ - Banking facilities offered by the banks and the level of customer satisfaction is presented in Table -14 . It indicates that thirty five respondents $(17.50 \%)$ are less satisfied, forty one respondents $(20.50 \%)$ are satisfied and the remaining one hundred and twenty four respondents $(62.00 \%)$ are highly satisfied with the E- Banking facilities offered by the banks.

Table 14: Opinion on E - Banking Facilities Offered by the Banks

\begin{tabular}{|c|c|c|c|c|}
\hline \multirow{2}{*}{$\begin{array}{c}\text { E- Banking } \\
\text { facilities }\end{array}$} & \multicolumn{3}{|c|}{ Level of Satisfaction } & \multirow{2}{*}{ Total } \\
\cline { 2 - 4 } & Low & Medium & High & \\
\hline Less Satisfied & $13(37.14 \%)$ & $11(31.43 \%)$ & $\begin{array}{c}11 \\
(31.43 \%)\end{array}$ & 35 \\
\hline Satisfied & $\begin{array}{c}16 \\
(39.02 \%)\end{array}$ & $12(29.27 \%)$ & $13(31.71 \%)$ & 41 \\
\hline Highly Satisfied & $\begin{array}{c}18 \\
(14.52 \%)\end{array}$ & $\begin{array}{c}25 \\
(20.16 \%)\end{array}$ & $\begin{array}{c}81 \\
(65.32 \%)\end{array}$ & 124 \\
\hline Total & 38 & 68 & 94 & 200 \\
\hline \multicolumn{4}{|c|}{$\chi^{2}$ value $=53.62$} \\
\hline
\end{tabular}

Source: Survey Data

Null Hypothesis: The association between the opinions of the respondents on the $\mathrm{E}$ - Banking Facilities offered by the Banks and their level of satisfaction is not significant.

Table - 14 reveals that majority of the respondents $(62.00 \%)$ are highly satisfied with the E - Banking Facilities offered by the Banks. It further indicates that the percentage of respondents with low level of satisfaction is the lowest $(14.52 \%)$ and the percentage of respondents with high level of satisfaction is the highest $(65.32 \%)$ among the respondents who are highly satisfied with the e- banking facilities offered by the banker. As the calculated $\chi^{2}$ value (53.62) is greater than the table value (9.488) at 5\% level of significance for 4 degrees of freedom, the null hypothesis is rejected and it could be concluded that the association between the opinion of the respondents on the E - Banking Facilities offered by the Banks and their level of satisfaction is significant. 


\section{N. Respondents' opinion on Overall Quality of Services of the Banker and Level of Satisfaction:}

The distribution of the respondents on the basis of their opinion on the overall Quality of services of the banker and the level of customer satisfaction is presented in Table - 15. It indicates that the overall quality of services of the banker is fair for thirty seven respondents (18.50\%), good for forty four respondents $(22.20 \%)$ and the same is excellent for the remaining one hundred and nineteen respondents $(59.50 \%)$.

Table 15: Opinion on Overall Quality of Services of the Banker

\begin{tabular}{|c|c|c|c|c|}
\hline \multirow{2}{*}{$\begin{array}{c}\text { Overall Quality } \\
\text { of Services }\end{array}$} & Low & Medium & High & \multirow{2}{*}{ Total } \\
\cline { 2 - 4 } & $14(37.84 \%)$ & $\begin{array}{c}13 \\
(35.14 \%)\end{array}$ & $\begin{array}{c}10 \\
(27.03 \%)\end{array}$ & 37 \\
\hline Fair & $11(25.00 \%)$ & $\begin{array}{c}22 \\
(50.00 \%)\end{array}$ & $\begin{array}{c}11 \\
(25.00 \%)\end{array}$ & 44 \\
\hline Good & $13(10.92 \%)$ & $\begin{array}{c}33 \\
(27.73 \%)\end{array}$ & $\begin{array}{c}73 \\
(61.34 \%)\end{array}$ & 119 \\
\hline Excellent & 38 & 68 & 94 & 200 \\
\hline Total & \multicolumn{4}{|c|}{$\chi^{2}$ value $=50.62$} \\
\hline
\end{tabular}

Source: Survey Data

Null Hypothesis: The association between the opinion of the respondents on the Quality of the Services of the Banks and their level of satisfaction is not significant.

Table - 15 reveals that majority of the respondents (59.50\%) opined that the overall quality of the services of the banks is excellent. It further indicates that the percentage of respondents with low level of satisfaction is the lowest $(10.92 \%)$ and the percentage of respondents with high level of satisfaction is the highest (61.34\%) among the respondents who opined that the overall quality of services rendered by the banker is excellent. As the calculated $\chi^{2}$ value (50.62) is greater than the table value $(9.488)$ at $5 \%$ level of significance for 4 degrees of freedom, the null hypothesis is rejected and it could be concluded that the association between the opinion of the respondents on the Quality of the Services of the Banks and their level of satisfaction is significant.

\section{STUdY RESUlts}

The results of the present study indicate that out of two hundred sample respondents, thirty eight respondents $(19.00 \%)$ derived low level of satisfaction, sixty eight respondents $(34 \%)$ derived medium level of satisfaction and the remaining ninety four respondents $(47.00 \%)$ derived high level of satisfaction on the services offered by the Foreign Sector Banks in Coimbatore District: The study further revealed that the following factors significantly influence the satisfaction derived by the respondents on the services offered by the Foreign Sector Banks in Coimbatore District:
a) Respondents' opinion on Account Opening Formalities:
b) Respondents' opinion on Working Hours of the Banks
c) Respondents' opinion on Interest Rate on Deposits
d) Respondents' opinion on Products offered by the

banks

e) Respondents' opinion on Loan sanctioning procedure

f) Respondents' opinion on quantum of loans sanctioned by the banks

g) Respondents' opinion on Efficiency of Staff

h) Respondents' opinion on Value Added Services offered by the banks

i) Respondents' opinion on time taken for serving the customers

j) Respondents' opinion on Ambiance Facilities in the Banks

k) Respondents' opinion on Customer Dispute Settlement Mechanism

1) Respondents' opinion on the customer relationship maintained by the banks

m) Respondents' opinion on the E - Banking facilities offered by the banks and

n) Respondents' opinion on Overall Quality of Services of the Banker

\section{SugGestions}

The following are the suggestions offered by the researchers for the purpose of enhancing the satisfaction of the customers on the services offered by the Foreign Sector Banks:

a) The banks should make themselves more customers centric by means of offering a wide range of products and services through multiple delivery channels in order to meet out the ever changing needs and wants of the customers.

b) The banks have to employ the technologies which must be user friendly. It will result in securing increased customer response and customer acceptance over the technologies employed by the banks and the same will result in improved means of utilization of the technology by the customers. This will lead to enhance the customer satisfaction.

c) The banks should formulate definite and concrete policies for conduct of customers meet at regular intervals and offer them an opportunity to express their views and grievances. This will make the customers to feel that the banks give adequate emphasis on their views and their needs. It will result in retention of existing customers and offering higher levels of satisfaction to them on the services offered by the banks.

d) By providing complete solutions to the problems of the customers with regard to the banking transactions, the customers' confidence can be gained and customers can effectively be retained by the banks and their level of satisfaction on the services of the banks can further be improved.

e) The need based services must be offered by the banks in order to meet out the varied demands of the customers 
and this will result in creating an intention in the minds of the customers that the banks offer superior quality of services and the same will result in enhancing their satisfaction on the services offered by the banks.

f) By means of setting the standards, the banks can find out the deviations between the actuals and the set standards and can take corrective actions to bring down the deviations between these two limits. It will result in offering a superior quality of services to the customers by the banks and enhance the satisfaction of the customers.

g) Offering of quality e-banking services will make the customers to feel that the services offered by the banks are superior in quality and the same will offer higher level of satisfaction to them on the services of the banks.

h) A separate customer grievance redressal cell has to be established to look after the complaints that have been lodged by the customer and this will result in reducing the deficiency in the services offered by the bankers to their customers. And also it is to be ensured that this cell finds effective and suitable means for solving the complaints that have been lodged by the customers. This will pave the way for improving the satisfaction of the customers.

i) Banks should look in to factors such as location, proximity to reach, availability of additional services like stationary, Xerox and postal, parking facilities and refreshment which are essential to the customers. When it comes to internal environment availability of various forms, provision of tables and chairs to fill the forms and take rest, installation of fans, drinking water and toilet facilities are much need to customers. By creating and providing these sorts of facilities and atmosphere, the banks can offer a higher level of customer satisfaction and offer a superior quality of services.

j) The banks have to adopt ways and means for speedy disposal of the request of the customers. Fixing of minimum and maximum time frame for each and every task will avoid annoyance among customers. Apart from this, the banks must also try to deliver exactly what the customers want and when they want it and the same will result in increased customer satisfaction.

k) Counter service is obviously important to any bank .Excellent counter service can improve the bank's ability to lure affluent prospects, elevate the bank's profitability, lower bank operation costs, and create greater customer loyalty. Hence, it is suggested that the foreign sector banks have to offer adequate amount of training to their staff who serve in counters and interact with the customers directly. The customers can derive higher level of satisfaction if they are able to secure prompt response from the bank staff.

1) Timely information to the customers definitely results in effective completion of work as well as more satisfaction to the customers. Hence, it is suggested that a separate cell has to be established in order to guide the customers. Apart from this, periodical review of progress of the customer requisition may help to complete of the task on time. The banks have to acquire customer's feedback after providing the service and this will help to improve the quality of the service offered by the banks to their customers.

m) Banks have been deploying ATMs to increase their reach. While ATMs facilitate a variety of banking transactions for customers, their main utility has been for cash withdrawal and balance enquiry. Most banks prefer to deploy ATMs at locations where they have a large customer base or expect considerable use. In addition to opening new ATMs to increase the usage of ATMs as a delivery channel, banks should also enter into bilateral or multilateral arrangements with other banks to have interbank ATM networks. The increase in number of ATM points will make the customers feel that the banks offer better quality of services.

\section{CONCLUSION}

The customer has been considered as the vital focus area in the sectors of the banking industry. As a result, the banks in the modern days in the highly competitive environment, lay down their emphasis on providing a superior quality of services to their customers and improving the satisfaction of their customers on their functioning. By offering better, diversified and customized products to fulfil the needs and wants of the customers, adopting an appropriate and reasonably stable policy towards the charges and costs, ensuring the effective utilization of the professional expertise possessed by the banks, adopting sophisticated and user friendly technologies and creating a trust in the minds of the customers on the bank will facilitate the banks to offer superior quality of services to the customers and offering an improved level of customer satisfaction. It is hoped that studies of this type and the suggestions offered through this study will be very much useful to the banks and it will pave a way for the Foreign Sector Banks to offer a superior quality of services to their customers and to enhance their satisfaction on the functioning of these banks.

\section{REFERENCES}

[1] K.C. Shekar, Banking Theory and Practice,. Vikas Publishing House Pvt Ltd.,Sahibabad, , Pp.7-9, 1994.

[2] Dr.Pawan Kumar Chugh., "Indian Banking Today: Impact of Reforms," Kanishka Publishers\& Distributors, Pp.163, New Delhi.

[3] Reserve Bank of India Annual Report 2010.

[4] L. Biff Motley, "Customer Satisfaction Vs Customer Service”, Bank Marketing, Washington, Vol.32(1), Pp.60-61, January 2000.

[5] Bryant Duhon., "Customer Service for Life", Bank Systems and Technology, New York, Vol.37 (7), Pp.A12- A14, July 10, 2000.

[6] Dr. M. Selvam, "Customer Satisfaction of Banking Services: An Over view", SAJOSPS, Pp.85, July -December 2005.

[7] Dr.R. Vijayakumar, "Consumers Satisfaction in Private Sector Banks in Coimbatore", Fortune Journal of International Management, Vol3, NO:2, Pp.109, July - December 2006.

[8] Dr.R. Vijayakumar, "Digital Banking", Organisational Management, Vol.XXIII, No:2, Pp.5, July-September 2007.

[9] Dr.R. Vijayakumar, and Dr.B. Kanagaraj, "Customers' perception on the services of New Generation Private Sector Banks in Coimbatore District", Pp.9, June 2008.

[10] Pooja Mengi "Customer Satisfaction with Service Quality: An Empirical Study of Public and Private Sector Banks", Pp.4, September, 2009. 
[11] Usha Lenka, Damodar Suar, Pratap K J Mohapatra "Service Quality, Customer Satisfaction, and Customer Loyalty in Indian Commrcial Banks", Pp.7, 2009.

[12] Saroj Kumar Datta "A causal relationship between Information Technology and customer satisfaction - a case study on Indian public sector banks", Pp.3, 2010.

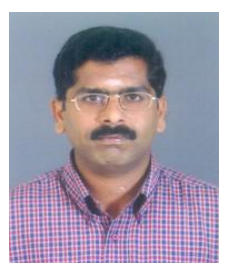

Dr.S. Thinakaran, is currently working as Associate Professor, GRD School of Commerce and International Business, Dr.GRD College of Science (Autonomous), Coimbatore, Tamilnadu. He is having more than fifteen years of teaching experience at both Under Graduate and Post Graduate levels. He has successfully presented five papers in various national seminars and conference. He has guided for M.Phil Research M.Phil programme under his guidance.

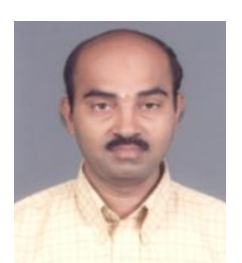

Dr. R. Vijayakumar M.Com., MBA. M.Phil.,Ph.D. , is currently serving as Assistant Professor in the Department of Commerce, Government Arts College (Autonomous), Coimbatore, Tamil nadu, He has more than seventeen years of teaching experience at both Under Graduation and Post Graduation Levels. He is specialised in Marketing and Human Resources Management. He has successfully guided nine Doctoral Research Scholars in Commerce and Management and eight M.Phil scholars. Currently eight Doctoral Research Scholars are pursuing research under his guidance in various areas. He has presented more than seventy papers in various National and International conferences and published twenty five research papers in various journals of national and international repute. 